\title{
Potensi dan Strategi Pengembangan Industri Sasirangan Kota Banjarmasin
}

\author{
Akhsanul Rakhmatullah \\ Faculty of Economics and Business, Lambung Mangkurat University, Indonesia \\ *E-mail corresponding author: akhsanul.rahmatullah@ulm.ac.id
}

\begin{abstract}
Received: 27-02-2021;
Accepted: 19-04-2021;

Available online: 30-04-2021

Ecoplan Vol. 4 No. 1, April 2021, hlm 45-53.
\end{abstract}

\section{ISSN p: 2620-6102 e: 2615-5575}

\begin{abstract}
Banjarmasin has strategic potential in supporting economic growth and has enormous potential to contribute to the Sasirangan Handicraft Industry sub-sector economy. This study aims to: a) analyze the Sasirangan handicraft industry value chain, b) analyze the strategic position of the Sasirangan handicraft industry, c) analyze the empowerment strategy of the Sasirangan handicraft industry in Banjarmasin City. The data used includes primary data obtained through interviews with 40 respondents of Sasirangan artisans in Banjarmasin City. From the research results, the results of the integration of VSA (Value Chain, SWOT, and Analytical Hierarchy Process) are a) The value chain of Sasirangan handicrafts consists of; Suppliers, Manufacturers of Sasirangan Handicraft products, traders, and end consumers. Lack of supply of raw materials for fabrics originating from the island of Java and capital. Meanwhile, the downstream side still lacks support from the Government in product marketing at the national level, b) From the results of the SWOT analysis, this industry is quite strong but faces significant challenges; these results indicate a strategy to improve skills and expertise as well as investment to improve the quality and production capacity to achieve efficiency, $c$ ) AHP results obtained marketing strategy to be a priority factor that determines the prospect of Sasirangan Craft. Recommendations from this study include a) Development of the One Village One Product program, in this case, One Sasirangan Village One Product Design, b) Development of the Sasirangan craft industry cluster, c) The government is more communicative regarding financing regulations for artisans, d) Establishing financial institutions and insurance in supporting the capital of MSMEs, e) Involving crafters, creative communities and business people intensively in promotional activities and exhibitions through roadshows, digital marketing, websites and government cooperation.
\end{abstract}

\author{
Keywords: Empowerment of \\ Sasirangan Craft industry, \\ Value Chain, SWOT, \\ Analytical Hierarchy Process
}

\begin{abstract}
Abstrak - Banjarmasin memiliki potensi strategis dalam menopang pertumbuhan ekonomi dan memiliki potensi yang sangat besar dalam menyumbang kontribusi Ekonomi dalam subsektor Industri Kerajinan Sasirangan. Penelitian ini bertujuan untuk : a) menganalisis rantai nilai industri kerajinan Sasirangan, b) menganalisis posisi strategis industri kerajinan Sasirangan, c) menganalisis strategi pemberdayaan industri kerajinan Sasirangan di Kota Banjarmasin. Data yang dipergunakan mencakup data primer yang diperoleh melalui wawancara dengan 40 responden perajin Sasirangan di Kota Banjarmasin. Dari hasil penelitian diperoleh hasil integrasi VSA (Value Chain, SWOT, dan Analitical Hierarchy Process) yaitu : a) Rantai nilai kerajinan Kerajinan Sasirangan terdiri dari ; Pemasok, Produsen produk Kerajinan sasirangan, trader dan konsumen akhir. Kekurangan pasokan bahan baku kain bahan yang berasal dari pulau jawa dan modal. Sedangkan sisi hilir masih kurangnya dukungan Pemerintah dalam pemasaran produk dalam tingkat Nasional, b) Dari hasil analisis SWOT, Industri ini cukup kuat namun menghadapi tantangan yang besar, hasil ini mengindikasikan pada strategi peningkatan ketrampilan dan keahlian serta investasi untuk meningkatkan kualitas dan kapasitas produksi untuk mencapai efisiensi, c) Hasil AHP diperoleh strategi pemasaran menjadi faktor prioritas yang menentukan prospek Kerajinan Sasirangan. Rekomendasi dari studi ini antara lain: a) Pengembangan program One Village One Product dalam hal ini Satu Kampung Sasirangan Satu Design Produk, b) Pengembangan klaster industri kerajinan Sasirangan, c) Pemerintah lebih komunikatif terkait regulasi pembiayaan bagi perajin, d) Membentuk lembaga keuangan dan asuransi dalam menunjang permodalan UMKM, e) Melibatkan perajin, komunitas kreatif dan para pelaku bisnis secara intensif dalam kegiatan promosi dan pameran melalui roadshow, digital marketing, website dan kerjasama pemerintah.
\end{abstract}

Kata Kunci: Pemberdayaan industri Kerajinan Sasirangan, Value Chain, WOT, AHP 


\section{PENDAHULUAN \\ Latar Belakang}

Pemerintah Provinsi Kalimantan Selatan belum memiliki regulasi baik Peraturan Daerah (Perda) maupun Peraturan Gubernur (Pergub) yang mengatur secara khusus dan spesifik tentang ekonomi kreatif, padahal sektor perbankan telah membuka peluang yang besar bagi para pelaku ekonomi kreatif untuk memanfaatkan pinjaman lunak dalam mengembangkan bisnis-bisnis yang mengedepankan kreativitas. Di sisi lain pembinaan yang diberikan kepada pelaku ekonomi kreatif juga belum merata pada tiap-tiap kabupaten, padahal pembinaan kepada pelaku ekonomi kreatif berbasis ekonomi lokal dapat memperluas jaringan dan inovasi sehingga produk yang dihasilkan dapat memiliki nilai jual yang tinggi. Satu hal yang perlu diperhatikan kembali adalah sarana pemasaran. Meskipun di Kalimantan Selatan sudah ada pasar yang menjual kerajinan khas Kalimantan Selatan, akan tetapi sarana promosi dan ruang khusus bagi pemasaran produk industri kreatif belum terkelola dengan baik.

Badan Ekonomi Kreatif (Bekraf) telah melaksanakan kunjungan ke Kota Banjarmasin tahun 2016. Setelah melakukan telaahan, disepakati bahwa Produk Unggulan Ekonomi Kreatif Kota Banjarmasin adalah pada subsektor Kriya, yaitu Kerajinan Sasirangan. Atas dasar hal tersebut, fokus kajian ini adalah subsektor Kriya dengan produk sasirangan konvensional dan sasirangan ramah lingkungan(pewarna alam).

Namun dalam perkembangannya, industri Kerajinan Sasirangan mengalami pasang surut bahkan 3 (tiga) tahun terakhir walaupun jumlah perajin meningkat dari 40 pengrajin pada tahun 2017 ada 9 perajin yang tidak meneruskan kembali usaha sasirangannya ditahun 2020, pada tahun 2020 terdapat 101 jumlah pengrajin sasirangan di Kota Banjarmasin. Selain itu, industri kerajinan Kerajinan Sasirangan juga mengalami permasalahan berupa terbatasnya modal dan sumber daya manusia, berdasarkan hasil survei awal menunjukkan bahwa banyak perajin yang mengalihkan Kegiatannya dari menjadi perajin sasirangan beralih profesi menjadi pedagang atau profesi yang lain yang lebih cepat mendatangkan uang terutama di kalangan generasi muda.

Selain masalah internal, industri kerajinan sasirangan juga menghadapai permasalahan yang berasal dari eksternal industri yang berupa ketatnya iklim persaingan usaha, terbatasnya sarana prasarana, implikasi otonomi daerah yang meningkatkan biaya produksi, implikasi perdagangan bebas yang menuntut agar industri bekerja dengan skala produksi yang efisien dan terbatasnya akses pasar yang membuat industri Kerajinan Sasirangan harus melakukan evaluasi. Kondisi ini memerlukan upaya serius dari pemerintah daerah untuk terus mengembangkan industri Kerajinan Sasirangan mulai dari hulu hingga hilir.

Berdasarkan potensi yang sangat besar atas keberadaan industri kerajinan Kerajinan Sasirangan di Kota Banjarmasin sebagai sektor penting dalam menyediakan lapangan kerja yang berarti sebagai salah satu penopang ketersediaan lapangan kerja dan sekaligus keberadaannya sebagai sumber kesejahteraan masyarakat baik secara langsung maupun tidak langsung.

Dilain pihak permasalahan yang dihadapi oleh industri Kerajinan Sasirangan juga dapat mengancam keberlangsungan hidup industri kecil yang secara otomatis menjadi ancaman bagi perusahaan hulu hilirnya, maka sangat layak sekali dilakukan studi lebih mendalam melalui penelitian tentang posisi strategis industri kerajinan Kerajinan Sasirangan dalam memberikan backward dan forward linkage bagi perkembangan sektor lainnya. Keterkaitan hulu hingga hilir melalui analisis rantai nilai (value chain) menjaga keberlangsungan industri Kerajinan Sasirangan, sehingga upaya untuk mendukung pemberdayaan industri kerajinan Sasirangan menjadi lebih integratif dan komprehensif.

\section{TINJAUAN PUSTAKA \\ Teori Pemberdayaan}

Pemberdayaan adalah terjemahan dari empowerment, sedang memberdayakan adalah terjemahan dari empower. Menurut Merriam Webster dan Oxford English Dictionary dalam Hutomo (2000), kata empower mengandung dua pengertian, yaitu:

1) to give power atau authority to atau memberi kekuasaan, mengalihkan kekuatan atau mendelegasikan otoritas ke pihak lain;

2) to give ability to atau enable atau usaha untuk memberi kemampuan atau keperdayaan.

Terdapat 4 konsep pemberdayaan ekonomi menurut Sumodiningrat (1999) dalam Hutomo (2000), secara ringkas dapat dikemukakan sebagai berikut:

1) Perekonomian rakyat adalah perekonomian yang diselenggarakan oleh rakyat. Perekonomian yang diselenggarakan oleh rakyat adalah perekonomian nasional yang berakar pada potensi dan kekuatan masyarakat secara luas untuk menjalankan roda perekonomian mereka sendiri;

2) Pemberdayaan ekonomi rakyat adalah usaha untuk menjadikan ekonomi yang kuat, besar, modern, dan berdaya saing tinggi dalam mekanisme pasar yang benar. Karena kendala pengembangan ekonomi rakyat adalah kendala struktural, maka pemberdayaan ekonomi rakyat harus dilakukan melalui perubahan struktural; 
3) Perubahan struktural yang dimaksud adalah perubahan dari ekonomi tradisional ke ekonomi modern, dari ekonomi lemah ke ekonomi kuat, dari ekonomi subsisten ke ekonomi pasar, dari ketergantungan ke kemandirian. Langkah-langkah proses perubahan struktur, meliputi: a) pengalokasian sumber pemberdayaan sumberdaya; b) penguatan kelembagaan; c) penguasaan teknologi; dan d) pemberdayaan sumberdaya manusia;

4) Pemberdayaan ekonomi rakyat, tidak cukup hanya dengan peningkatan produktivitas, memberikan kesempatan berusaha yang sama, dan hanya memberikan suntikan modal sebagai stumulan, tetapi harus dijamin adanya kerjasama dan kemitraan yang erat antara yang telah maju dengan yang masih lemah dan belum berkembang;

5) Kebijakannya dalam pembedayaan ekonomi rakyat adalah: a) pemberian peluang atau akses yang lebih besar kepada aset produksi (khususnya modal); b) memperkuat posisi transaksi dan kemitraan usaha ekonomi rakyat, agar pelaku ekonomi rakyat bukan sekadar price taker; c) pelayanan pendidikan dan kesehatan; d) penguatan industri kecil; e) mendorong munculnya wirausaha baru; dan f) pemerataan spasial;

6) Kegiatan pemberdayaan masyarakat mencakup: a) peningkatan akses bantuan modal usaha; b) peningkatan akses pengembangan SDM; dan c) peningkatan akses ke sarana dan prasarana yang mendukung langsung sosial ekonomi masyarakat lokal.

\section{Pemberdayaan usaha kecil}

Upaya pemberdayaan ekonomi masyarakat tidak terlepas dari perluasan kesempatan kerja dan peningkatan pendapatan masyarakat. Terkait dengan pemberdayaan masyarakat dalam memperluas kesempatan kerja, maka dipengaruhi salah satunya oleh kebijakan pengembangan Usaha Mikro, Kecil dan Menengah (UMKM). Pengembangan UMKM terutama Usaha Kecil Menengah (UKM), memiliki potensi yang strategis dalam rangka pemberdayaan masyarakat, mengingat pertumbuhan dan aktifnya sektor riil yang dijalankan oleh UKM mampu memberikan nilai tambah bagi masyarakat, yaitu tersedianya lapangan kerja dan meningkatnya pendapatan. Hal ini menunjukkan bahwa kelompok UKM dapat menjadi penyeimbang pemerataan dan penyerapan tenaga kerja.

Salah satu hal yang dapat mendukung berkembangnya suatu UKM agar tercipta perekonomian yang kokoh adalah faktor modal. Hingga saat ini faktor modal berupa kredit usaha masih diusahakan pemerintah dan tercantum dalam kebijakannya. Seperti yang telah disebutkan dalam kebijakan pemerintah di atas, pemerintah melakukan kegiatan pokok di bidang permodalan di antaranya adalah memperluas, memperkuat, dan memfasilitasi sumber-sumber pembiayaan serta meningkatkan kredit skala mikro dan kecil. Dengan demikian, permodalan menjadi faktor yang penting bagi kemajuan UKM dalam rangka menguatkan ekonomi nasional meskipun dalam kenyataannya, beberapa pelaku UKM masih mengalami kesulitan dalam memperoleh kredit tersebut.

Berbagai upaya telah dilakukan Pemerintah dalam upaya mengembangkan UKM melalui pemberdayaan, salah satunya melalui kebijakan Pemerintah yang dituangkan dalam UU No. 20/2008 tentang UMKM, khususnya dalam pasal 7 ayat 1 sangat jelas dinyatakatan bahwa pemerintah dan pemerintah daerah menumbuhkan iklim usaha dengan menetapkan peraturan perundang-undangan dan kebijakan yang meliputi aspek:1)Pendanaan, 2)Dukungan Pemerintah, 3) Kemitraan.

\section{Analisis industri}

Suatu industri didefinisikan sebagai suatu perusahaan yang menawarkan produk atau jasa yang saling mengganti satu sama lain dan memberikan kepuasan yang sama bagi konsumen. Tugas yang dihadapi oleh seorang manajer adalah menganalisis kekuatan pesaing dalam lingkungan industri yang dapat memberikan peluang dan ancaman bagi perusahaan. Untuk keperluan itu, maka kerangka kerja yang dikembangkan oleh Michael E. Porter dapat membantu manajer dalam membuat analisis yang disebut dengan Model Lima Kekuatan (The Five Forces Model) adalah sebagai berikut : 1) Persaingan antar unit-unit di dalam industri (Rivalry Among Existing Firms), 2) Resiko masuknya pesaing baru (Threat of New Entrants), 3) Kemampuan tawar menawar dari pembeli (Bargaining Power of Buyers), 4) Kemampuan tawar menawar dari supplier (Bargaining Power of Suppliers), 5) Ancaman jasa pengganti (Threat of Subtitute Services).

\section{Strategi pemberdayaan industri kecil}

Strategi pengembangan industri kecil adalah pendekatan-pendekatan yang digunakan dalam pengembangan industri kecil (Deperindag, 2002).

1.Pendekatan Pembangunan

Dalam menyelesaikan objek pengembangan industri baik yang bersifat pemecahan masalah (problem solving) maupun bersifat pengembangan ke depan (development oriented), strategi pemberdayaan yang ditempuh didasarkan pada pola pendekatan melalui dua langkah simultan yang bersinergi seperti : 
a. Memperkuat daya tarik faktor-faktor pada sisi permintaan pada produk industri (demand pull industri) melalui berbagai upaya yang sesuai dengan keadaan dan kebutuhan.

b. Memperkuat daya dukung faktor pendorong pada sisi kemampuan daya pasok(supply push strategy) untuk memperlancar kegiatan produksi secara berdaya saing sesuai kondisi dan kebutuhan.

2. Penerapan Strategi Pemberdayaan

Pendekatan pembangunan dpat diterapkan pada semua skala pembinaan dari level sktor maupun kelompok industri di tingkat nasional secara makro sampai tingkat sentra industri dan unit usaha secara mikro, namun pertimbangan efisiensi karena keterbatasan sumber daya maka dilakukan penetapan prioritas pembinaan atau pengembangan industri kecil. Pendekatan sentra industri kecil menengah ditempuh dengan kecenderungan pada persaingan yang menuntut bergesernya pola persaingan individu ke arah pola persaingan secara kolektif menuju daya saing global.

\section{Rantai nilai}

Secara definisi rantai nilai adalah alat analisis stratejik yang digunakan untuk memahami secara lebih baik terhadap keunggulan kompetitif, untuk mengidentifikasi dimana value pelanggan dapat ditingkatkan atau penurunan biaya, dan untuk memahami secara lebih baik hubungan perusahaan dengan pemasok/supplier, pelanggan, dan perusahaan lain dalam industri. Value Chain mengidentifikasikan dan menghubungkan berbagai aktivitas stratejik di perusahaan.

Tujuan dari analisis value-chain adalah untuk mengidentifikasi tahap-tahap value chain di mana perusahaan dapat meningkatkan value untuk pelanggan atau untuk menurunkan biaya. Penurunan biaya atau peningkatan nilai tambah (Value added) dapat membuat perusahaan lebih kompetitif.

Strategi diferensiasi biasanya menekankan pada kualitas unggulan. Beberapa perusahaan yang sukses melakukan hal ini antara lain: Apple dari USA yang bergerak di bidang teknologi berhasil menempatkan produknya mempunyai nilai unggul, dalam hal kualitas dan branding yang sangat baik, sehingga seperti: produk produk smartphone maupun Personal Computer menggunakan design Apple sebagai acuannya dibandingkan pesaing yang menawarkan harga murah sampai mempunyai pelanggan yang fanatik, begitu juga dengan produk Apple.

\section{METODOLOGI PENELITIAN LOKASI PENELITIAN}

Lokasi penelitian ditentukan di Kota Banjarmasin dengan pertimbangan karena Kota Banjarmasin memiliki industri kecil Kerajinan Sasirangan dengan jumlah unit usaha sebanyak 40 Pengrajin Sasirangan.

\section{METODE DAN OBJEK PENELITIAN}

Dalam studi ini sesuai dengan tujuan penelitian akan digunakan beberapa alat analisis baik melalui metode kualitatif maupun kuantitatif yang diharapkan mampu menjawab permasalahan dan tujuan yang akan dicapai. Subjek penelitian adalah Perajin Sasirangan, Dinas Perindustrian dan Perdagangan serta SKPD terkait Pemerintahan Kota Banjarmasin.

Objek penelitian merupakan apa yang hendak diselidiki dalam penelitian. Dalam studi ini objek penelitiannya adalah menganalisis rantai nilai industri kerajinan Sasirangan, menentukan posisi strategis industri kerajinan kerajinan Sasirangan dan penentuan strategi pemberdayaan industri kerajinan kerajinan Sasirangan di Kota Banjarmasin.

\section{DEFINISI OPERASIONAL VARIABEL}

1) Variabel dalam Rantai Nilai terdiri dari : a.Pasar akhir(end market) adalah masyakrakat pengguna barang untuk kegiatan konsumsi. b.Lingkungan Penunjang adalah faktor-faktor diluar industri yang berperan menunjang aktifitas perusahaan, c.Pasar pendukung(supporting markets) adalah jasa pendukung aktifitas industri.

2) Variabel dalam analisis SWOT terdiri dari : Kekuatan (strengths), Kelemahan (weakness), Peluang (opportunities), Ancaman (threats).

3) Variabel dalam Analytical Hierarcy Process (AHP) terdiri dari:

a. Hierarki level 1 untuk mengetahui proyeksi pengembangan kerajinan sasirangan.

b. Hierarki level 2 untuk melihat proyeksi pengembangan kerajinan sasirangan dalam strategi pengelolaaan keuangan, pengembangan SDM, Pemasaran dan pelayanan publik.

c. Hierarki level 3 untuk melihat faktor yang mempengaruhi proyeksi pengembangan kerajinan sasirangan yang terdiri dari pengelolaan keuangan, harga pokok produksi, kredit perbankan, Pendidikan dan pelatihan, sistem pengupahan, pemasaran lokal, digital marketing, design dan inovasi, 
standarisasi produk, penelitian pasar, pembinaan, fasilitas pameran produk hak paten produk.

d. Hierarki level 4 untuk melihat proyeksi pengembangan kerajinan sasirangan yang terdiri dari scenario optimis, sekenario status quo dan skenario pesimis.

4. Analisis rantai nilai adalah analisis yang diperoleh dari tanggapan responden terkait dengan tahapan aktifitas produksi mulai dari input hingga pemasaran produk sampai ke tangan konsumen melalui pengisian pertanyaan terstruktur dan wawancara mendalam pada sampel perajin sasirangan di Kota Banjarmasin.

5. SWOT adalah analisis yang bertujuan untuk menentukan strategi sektor unggulan yang dapat di rumuskan berdasarkan pembobotan penilaian responden atas pertanyaan terstruktur.

6. AHP adalah suatu model permasalahan yang tidak mempunyai struktur untuk memecahkan masalah yang terukur (kuantitatif) yang memerlukan pendapat (judgement) responden yang expert pada permasalahan industri kecil kerajinan Sasirangan di Kota Banjarmasin.

\section{JENIS DAN SUMBER DATA}

Data-data yang digunakan dalam penelitian ini terdiri dari data primer kuantitatif dan kualitatif yang diperoleh dengan melakukan survei lapangan serta data sekunder sebagai supporting data berupa existing statistic data.

1) Data Primer. Data ini diperoleh melalui survei lapangan (face to face interview).

2) Data Sekunder. Pengumpulan data yang berupa existing statistic data dilakukan dengan mengumpulkan data-data statistik daerah yang berasal dari berbagai laporan yang diberikan oleh lembaga pemerintah seperti BPS, Disperindag, Dinas Koperasi dan UMKM, Disnaker, Pemerintah Kota Banjarmasin.

\section{POPULASI DAN SAMPEL}

Populasi dalam penelitian ini adalah industri kecil kerajinan sasirangan yang tergolong dalam UMKM di Kota Banjarmasin berdasarkan jumlah pekerja. Jumlah industri adalah sebanyak 40 perajin sasirangan. Jumlah sampel dalam penelitian ini adalah seluruh pengrajin sasirangan di Kota Banjarmasin sebanyak 40 perajin.

\section{TEKNIK ANALISIS DATA}

\section{ANALISIS EKONOMI RANTAI NILAI}
a. End Market (Pasar Akhir)
b. Usaha dan Lingkungan Penunjang
c. Hubungan Vertikal
d. Hubungan Horizontal
e. Supoorting MarketS
f. (Pasar Pendukung)

\section{ANALISIS SWOT}

Untuk Melihat Posisi Strategis Industri Kerajinan Sasirangan.

\section{ANALYTICAL HIERARCY PROCESS (AHP)}

Untuk Melihat Strategi Pemberdayaan Industri Kerajinan Sasirangan.

\section{HASIL DAN PEMBAHASAN}

\section{Analisis Rantai Nilai Industri Kerajinan Sasirangan}

Nilai jual tinggi produk kerajinan sasirangan ditentukan oleh nilai tambah yang didapatkan dalam setiap mata rantai produksi produk kerajinan. Nilai ekonomis produk akhir di pasar sangat bergantung pada tahapan produksi mulai dari penyediaan input produksi, proses produksi hingga penangangan pasca produksi. Rantai nilai produk merupakan aktifitas yang berawal dari bahan baku hingga penanganan purna jual dan mencakup aktifitas yang saling terkait hubungan dengan pemasok (supplier linkage) dan hubungan dengan konsumen (consumer linkage).

Industri kerajinan sasirangan merupakan salah satu industri yang memiliki rangkaian rantai nilai yang sederhana. Pelaku usaha yang terlibat didalam rantai nilai kerajinan sasirangan mulai dari pemasok bahan baku, perajin, pedagang, dan konsumen atau pengguna akhir dari produk sasirangan. Kualitas dan kuantitas hasil produksi ditentukan oleh peran pelaku usaha dalam memberikan kontribusi pada tiap tahapan rantai nilai. Oleh karena itu setiap pelaku usaha saling berkaitan dengan pelaku usaha lain dalam menunjang kontinuitas distribusi produk.

Rantai nilai industri kerajinan sasirangan di Kota Banjarmasin. Dalam rantai tersebut terdapat banyak 
organisasi dan jaringan kerja yang terlibat dengan fungsi-fungsi penting yang saling berinteraksi. Masingmasing pelaku pada rantai nilai memiliki sebuah peran dan fungsi yang berbeda. Hubungan antar fungsi mencerminkan kekuatan dan kelemahan yang penting dari sebuah sistem kelembagaan. Seluruh hubungan terjadi dalam koridor kebijakan, hukum, insentif dan serangkaian sumberdaya yang memungkinkan beroperasinya sejumlah lembaga.

Berikut adalah peran dan fungsi dari masing-masing pelaku usaha dalam rantai nilai kerajinan sasirangan.

1. Industri Inti

Industri inti atau utama adalah perusahaan pembuat produk jadi kerajinan sasirangan yaitu perajin yang siap untuk dipasarkan. Usaha-usaha ini dapat memasarkan produknya secara langsung kepada pembeli di luar negeri dan dalam negeri (merangkap sebagai pedagang/eksportir) atau hanya produsen murni. Skala perusahaan yang berada dalam kelompok industri ini terdiri dari perusahaan kecil, mikro dan menengah.

Dalam upaya untuk memenuhi permintaan pasar, perajin melakukan spesialisasi terhadap produk sasirangan yang dapat berasal dari bahan baku atau jenis pewarnaan alam/ramah lingkungan, desain dan kualitas. Segmentasi pasar bagi produk sasirangan dilakukan untuk menjaga daya saing industri terhadap pesaing baik dari dalam dan luar negeri. Oleh karena itu dibutuhkan keahlian yang memadai dari perajin untuk selalu mengembangkan inovasi produk baik terhadap model dan kualitas bahan baku. Kendala permodalan juga masih dihadapi oleh perajin dalam mengembangkan usaha. Masih minimnya aksessibilitas pembiayaan usaha melalui lembaga keuangan khususnya perbankan menjadi permasalahan klasik.

Dari sisi kelembagaan, masih kurangnya dukungan Pemerintah Kota Banjarmasin dalam proses pendampingan dan pembinaan perajin sasirangan untuk pemberdayaan usahanya, baik melalui pelatihan sumberdaya manusia maupun pemanfaatan teknologi tepat guna. Kurangnya dukungan Dinas Pariwisata dalam proses promosi dimana industri produksi sasirangan dapat dijadikan sebagai suatu tempat destinasi wisata edukasi, sehingga perajin melakukan promosi secara individu untuk meningkatkan hasil penjualannya Kurangnya dukungan Dinas Koperasi khususnya dalam pembinaan koperasi atau kelompok-kelompok perajin sasirangan agar dapat mengembangkan usahanya melalui menajemen kelompok.

2. Industri Pendukung

a. Industri Sasirangan Primer.

Industri Sasirangan primer merupakan sumber bahan baku dari industri kerajinan sasirangan. Keberadaan Industri primer ini tidak berada dalam suatu wilayah yang sama dengan lokasi industri kerajinan sasirangan, meskipun demikian yang penting adalah terdapatnya suatu yang tak terputus. Perusahaan penyedia bahan baku merupakan bagian dari industri pendukung.

b. Industri Pelapis Permukaan.

Industri ini menyediakan bahan-bahan untuk melapisi permukaan sasirangan yang menjadi proses finishing dalam produk sasirangan. Peranan industri ini sangat penting dalam memberikan nilai tambah produk sasirangan.

c. Industri Pengemasan dan Jasa

Transportasi.

Industri pengemasan dan jasa transportasi merupakan industri pendukung dalam membantu kelancaran usaha industri kerajinan sasirangan dalam memenuhi permintaan pasar.

3. Industri Penyedia Jasa

Dukungan penelitian dan pemberdayaan baik itu milik pemerintah dan swasta akan memberikan kontribusi sebagai contoh dalam bahan baku baru (alternatif) dan sifat-sifatnya, serta uji kualitas produk.

Sementara khusus untuk produk sasirangan berorientasi ekspor, peran jasa pelabuhan atau kepabeanan menjadi sangat penting agar dapat mempertahankan daya saing. Prosedur kepabeanan perlu dipermudah tanpa mengurangi pengawasan agar pengiriman barang ekspor sesuai dengan jadwal kontrak dan biaya-biaya yang ditimbulkan tidak membebani industri. Lembaga keuangan seperti perbankan daerah memiliki peranan yang penting untuk mendukung permodalan yaitu modal kerja dan investasi dalam peningkatan kemampuan produksi industri kerajinan sasirangan.

4. Lembaga Pendukung

a) Pemerintah Daerah, b) Pemerintah Pusat, c) Asosiasi Perajin Sasirangan, d) Kamar Dagang dan Industri (KADIN), e) Perguruan Tinggi, f) Lembaga Pendidikan dan Pelatihan.

\section{Analisis posisi strategis industri kerajinan sasirangan kota Banjarmasin}

Analisis Strengths, Weakness, Opportunity dan Threats (SWOT) merupakan teknik analisis yang dapat memetakan posisi strategis keberadaan industri kerajinan sasirangan. Analisis SWOT adalah indentifikasi terhadap berbagai faktor secara sistematis untuk merumuskan strategi. Analisis ini didasarkan pada logika yang 
dapat memaksimalkan kekuatan (strengths) dan peluang (opportunities), namun secara bersamaan dapat meminimalkan kelemahan (weaknesses) dan ancaman (threats). Proses pengambilan keputusan strategis selalu berkaitan dengan pengambilan misi, tujuan, strategi, dan kebijakan perusahaan (Rangkuti, 2000).

Pemetaan posisi strategis industri kerajinan sasirangan di Kota Banjarmasin Berikut adalah identifikasi faktor- faktor posisi strategis industri kerajinan sasirangan di Kota Banjarmasin. Faktor kekuatan dalam matrik SWOT mencakup beberapa komponen yang menjadi kekuatan internal industri kerajinan sasirangan yaitu antara lain keberadaan dalam kluster, ketersediaan tenaga kerja, stabilitas harga produk, adanya pola kemitraan, keterampilan dan proses produksi yang sederhana, potensi pasar, kualitas bahan baku dan fleksibilitas diversifikasi usaha.

Di sisi lain industri kerajinan sasirangan memiliki beberapa kendala internal antara lain keterbatasan aksesibilitas modal, penguasaan teknologi yang rendah dan kualitas manajerial rendah, terbatasnya pasar dan masih rendahnya inovasi produk. Sementara dari sisi eksternal, industri kerajinan sasirangan memiliki beberapa peluang yaitu membaiknya kondisi perekonomian sehingga permintaan semakin meningkat, adanya dukungan pemerintah dan peluang pasar internasional. Ancaman juga akan dihadapi industri antara lain dinamika bisnis dan perekonomian dan dinamika pasar global yang semakin cepat dan tanpa ada batas antar negara.

Tabel 1 : Diagram Matriks SWOT Posisi Strategis Industri Kerajinan Sasirangan

\begin{tabular}{|c|c|}
\hline $\begin{array}{c}\text { Strategi S-O } \\
\text { Strategi yang menggunakan } \\
\text { kekuatan untuk } \\
\text { memanfaatkan peluang, } \\
\text { yaitu: }\end{array}$ & $\begin{array}{c}\text { Strategi W-O } \\
\text { Strategi yang } \\
\text { minimalisir kelemahan } \\
\text { untuk memanfaatkan } \\
\text { peluang: }\end{array}$ \\
\hline $\begin{array}{c}\text { “Strategi Meningkatkan } \\
\text { Kualitas dan Kapasitas } \\
\text { Produksi Untuk } \\
\text { Perluasan Pasar" }\end{array}$ & $\begin{array}{c}\text { “Strategi Peningkatan } \\
\text { Intensitas Pelatihan } \\
\text { Untuk Spesialisasi } \\
\text { Produk dan Dukungan } \\
\text { Modal Guna } \\
\text { Meningkatkan Kapasitas } \\
\text { Produksi " }\end{array}$ \\
\hline $\begin{array}{c}\text { Strategi S-T } \\
\text { Strategi yang menggunakan } \\
\text { kekuatan untuk mengatasi } \\
\text { ancaman }\end{array}$ & $\begin{array}{c}\text { Strategi W-T } \\
\text { Strategi yang } \\
\text { meminimalisir kelemahan } \\
\text { untuk mengatasi ancaman }\end{array}$ \\
\hline $\begin{array}{c}\text { “Strategi Peningkatan } \\
\text { ketrampilan dan } \\
\text { Investasi Guna } \\
\text { Meningkatkan Kualitas } \\
\text { dan Kapasitas Produksi } \\
\text { Untuk Mencapai } \\
\text { Effisiensi” }\end{array}$ & $\begin{array}{c}\text { "Strategi Penggunaan } \\
\text { Teknologi Tepat Guna } \\
\text { dan Mendatangkan } \\
\text { Investor" }\end{array}$ \\
\hline
\end{tabular}

Beberapa strategi terpadu tersebut adalah (1) Strategi meningkatkan kualitas dan kapasitas produksi untuk perluasan pasar, (2) Strategi peningkatan intensitas pelatihan untuk spesialisasi produk dan dukungan permodalan, (3) Strategi peningkatan ketrampilan dan investasi untuk meningkatkan kualitas dan kapasitas produksi untuk mencapai efisiensi, (4) Strategi penggunaan tekhnologi tepat guna dan meningkatkan daya tarik investasi

\section{Analytical Hierarchy Process (AHP) Industri Kerajinan Sasirangan}

Berdasarkan hasil analisis dengan metode Analytical Hierarchy Process (AHP) pada sepuluh orang yang dianggap expert dalam pengembangan industri kerajinan sasirangan, diperoleh hasil sebagaimana bahwa strategi pemasaran menjadi faktor prioritas yang menentukan prospek kerajinan sasirangan di Kota Banjarmasin. Keterbatasan perajin dalam mengakses pasar menjadi kendala utama bagi para perajin dalam memasarkan produk sasirangan. Promosi merupakan salah satu aspek penting dalam pemasaran terutama memberikan informasi pada pasar mengenai produk yang dijual. Teknik pemasaran melalui media digital menjadi pilihan prioritas 
dibandingkan dengan pemasaran lokal dan rencana cluster yang selama ini dilakukan. Media digital dianggap sebagai media paling efektif sejalan dengan semakin berkembangnya teknologi informasi.

Pemerintah Kota Banjarmasin wajib memiliki program bidang pemasaran yang dilakukan melalui promosi besar-besaran dibidang pariwisata ke manca Negara melalui Sasirangan Pewarna Alam karena Sasirangan ramah lingkungan ini mempunyai market besar di dunia Internasional, sedangkan untuk pasar nasional bisa menggunakan sasirangan konvensional dengan motif yang sederhana dan warna pastel sedangkan untuk pasar lokal tetap dengan warna terang dengan design penuh corak yang paling disukai oleh msyarakat lokal.

Berdasarkan hasil analisis AHP diketahui bahwa pemberdayaan industri kerajinan sasirangan merupakan suatu hal yang mutlak diperlukan guna mewujudkan kerajinan sasirangan yang memiliki kemampuan bersaing (competitive advantage) di pasar domestik, regional maupun internasional, dengan mengemban misi peningkatan mutu produk, memperluas pangsa pasar dan memperkuat jaringan pemasaran bagi produk-produk sasirangan. Sementara itu lingkungan strategis industri sasirangan masih dihandalkan pada berbagai kendala baik intern maupun ekstern. Kendala intern terlihat dari rendahnya mutu SDM, terbatasnya modal, teknologi dan kerjasama usaha. Sedangkan kendala ekstern ditandai oleh belum kondusifnya lingkungan bisnis dan belum memadainya infrastruktur.

Disisi lain industri sasirangan mempunyai celah-celah yang dapat menjadi peluang untuk bangkit dalam memenangkan persaingan yaitu globalisasi dan reformasi ekonomi, keberpihakan pemerintah yang kuat terhadap industri Sasirangan oleh karena itu industri kerajinan sasirangan ditantang untuk meningkatkan daya saing dan pangsa pasarnya, menguatkan dan memperluas basis usaha dan kewirausahaannya, memperkukuh struktur dunia usaha yang diisi oleh UMKM dan memulihkan serta mengembangkan kemampuan untuk keluar dari krisis ekonomi maupun pandemic COVID-19 yang saat ini sedang dihadapi. Untuk kepentingan tersebut, dukungan Pemerintah terhadap pemberdayaan industri kerajinan sasirangan menjadi faktor sangat penting.

Pemerintah seyogyanya mampu membuat berbagai kebijakan yang memperkuat daya tarik industri kerajinan sasirangan seperti menciptakan iklim usaha yang baik yang didukung oleh tumbuhnya kemitraan dari industri hulu dan hilir maupun kemudahan mendapatkan HKI. Selain itu juga, diperlukan juga kebijakan Pemerintah yang memperkuat daya dukung faktor-faktor pendorong daya saing industri kerajinan Sasirangan yang terkait dengan ketersediaan bahan baku Sasirangan yang semakin sulit didapat, dukungan permodalan dan peningkatan kemampuan sumber daya manusia dalam melakukan inovasi produk.

\section{PENUTUP}

Dari tiga model analisis yang di gunakan dalam penelitian diperoleh hasil untuk pemberdayaan ekonomi industri kerajinan sasirangan secara optimal adalah sebagai berikut : 1) Berdasarkan hasil analisis rantai nilai diketahui bahwa rantai nilai kerajinan sasirangan terdiri dari; Pemasok, Produsen produk sasirangan dan Konsumen akhir. Kendala yang dihadapi perajin di tingkat hulu yaitu proses produksi kekurangan pasokan bahan baku kain yang berasal dari pulau jawa dan modal. Sedangkan kendala di hilir kurangnya kolaborasi pentahelix ABCGM (Akademisi, Pelaku Bisnis, Komunitas, Pemerintah dan Media) dalam proses pemasaran dan sarana pamer produk hasil kerajinan sasirangan di tingkat nasional maupun global.

2) Berdasarkan hasil analisis SWOT, diperoleh hasil pemetaan posisi strategis industri kerajinan sasirangan ada pada kuadran II yang menandakan industri cukup kuat namun menghadapi tantangan yang besar, hasil ini mengindikasikan pada strategi peningkatan ketrampilan dan keahlian serta investasi untuk meningkatkan kualitas dan kapasitas produksi untuk mencapai efisiensi.

3) Hasil Analytical Hierarchy Process (AHP) posisi strategis indutri kerajinan sasirangan berada pada skenario yang optimis. Untuk menjalankan skenario optimis dalam pemberdayaan industi kerajinan sasirangan dibutuhkan strategi prioritas yaitu strategi pemasaran terutama melalui Digital Marketing.

\section{DAFTAR PUSTAKA}

Cahyana, A. and Sukayasa, K. W. (2009) Kajian Karakteristik Bahan Baku dan Proses Produksi Kria Tradisional Anyaman di Tasikmalaya Jawa Barat. Bandung.

Dedi Purwana ES.2017.’Pemanfaatan Digital Marketing Bagi Usaha Mikro, Kecil dan Menengah (UMKM) di Kelurahan Malaka Sari, Duren Sawit”. Jurnal Pemberdayaan Masyarakat Madani (JPMM). Vol. 1 No. 1 Juli

Intan, A.H. E., Gumbira, S., dan Saptono I. T. 2003. Strategi Pengembangan Industri Pengolahan Sabut Kelapa Nasional (Strategy on the Development of National Coir Processing Industry). Jurnal Manajemen \& Agribisnis. Vol. 1 No. 1 April 2003. P. 42-54.

Kodrat, D. S. Manajemen Strategi: Membangun Keunggulan Bersaing Era Global di Indonesia Berbasis Kewirausahaan. Yogyakarta: Graha Ilmu 
Kuncoro, M. 2001. Metode Kuantitatif: Teori dan Aplikasi untuk Bisnis dan Ekonomi. Yogyakarta: UPP-AMP YKPN.

Kurniawan Paulus K dan Supomo, I. A. 2003. Analisis Formasi Ketrekaitan, Pola Kluster dan Orientasi Pasar: Studi Kasus Sentra Industri keramik di kasongan Kabupaten Bantul D.I Yogyakarta. Jurnal Empirika, Volume 16. Juni. No.1. p. 1-20.

Lila Bismala, 2016. "Model Manajemen Usaha Mikro Kecil dan Menengah (UMKM) untuk Meningkatkan Efektivitas Usaha Kecil Menengah". Jurnal Entrepreneur dan Entrepreneurship, Volume 5, Nomor 1,Hal 23

Ni Nyoman Sunariani, AAN. Oka Suryadinatha Ida IDM Rai Mahaputra. 2017 "Pemberdayaan Usaha Mikro Kecil dan Menengah (UMKM) Melalui Program Binaan di Provinsi Bali” Jurnal Ilmiah Manajemen dan Bisnis :Volume 2 No 1.Hal 5-16

Supriyadi, H. (2007) Kewirausahan UMKM, Pemikiran dan Pengalaman; Membangun Hubungan Pemasaran Relational pada Usaha Kecil dan Menengah (UKM) di Surabaya. Yogyakarta: Graha Ilmu.

Soebagiyo, D. dan Wahyudi, M. 2008. Analisis Kompetensi Produk Unggulan Daerah Pada Batik Tulis dan Cap Solo di Dati II Kota Surakarta. Jurnal Ekonomi Pembangunan. Vol. 9. No. 2. Desember. Hal 184-197.

Sondhy Purwoko, Agung Budi Darmawan.2015."Model Pengembangan Usaha Mikro Kecil Menengah (UMKM) dengan One Village One Product (OVOP) Untuk Meningkatkan Daya Saing Nasional dan Globa"l.Dinas Koperasi dan UMKM Jawa Tengah. 